\title{
Preservação de figos em atmosfera com alto teor de gás carbônico por curto período.
}

\author{
Franciane Colares Souza Usberti (Prof Doutor), Daniele de Souza Henzler (IC) \\ Resumo \\ O presente trabalho tem por objetivo avaliar o efeito da exposição de figos em 4 e 8 horas à atmosfera com \\ $100 \%$ de gás carbônico armazenados em temperaturas de $10^{\circ} \mathrm{C} \mathrm{e} 20^{\circ} \mathrm{C}$, identificando as melhores \\ condições de armazenamento para manutenção da qualidade e o tempo de armazenamento da fruta.
}

Palavras Chave: Atmosfera modificada, armazenamento, microbiologia.

\section{Introdução}

No Brasil, segundo maior exportador de frutas in natura do mundo, a cultura da figueira tem grande importância. Contudo, figos maduros indicados para a comercialização são delicados, altamente perecíveis e vulneráveis à contaminação por fungos e insetos. Assim, a qualidade inicial dessas frutas é fundamental para a sua vida em pós-colheita, razão pela qual é recomendada a utilização de métodos que possibilitem controle do crescimento de microrganismos (CUNHA, 2011). Dentre eles, pode-se citar o aumento nas concentrações de gás carbônico em processos de atmosfera modificada, uma vez que elevados níveis de $\mathrm{CO}_{2}$ apresentam efeitos fungistáticos e bacteriostáticos, que aumentam a fase de adaptação e diminuem a taxa de crescimento dos microrganismos (THOMPSON, 2010). Este projeto teve como objetivo verificar as possíveis respostas do fruto quando exposto à atmosfera com alta concentração de gás carbônico em curtos períodos armazenado em diferentes temperaturas.

\section{Resultados e Discussão}

A avaliação da qualidade do produto foi realizada em 4 dias (dia 0 , dia 2 , dia 4 e dia 6 ), utilizando-se os parâmetros aparência, cor, perda de massa, $\mathrm{pH}$, sólidos solúveis, acidez titulável, vitamina C, pigmentação e contaminação microbiológica. Os resultados mais notáveis estão representados na Tabela 1 e na Figura 1.

Tabela 1. Valores médios da contagem de fungos e leveduras (UFC/g) para os tratamentos armazenados à $10^{\circ} \mathrm{C}$ e $20^{\circ} \mathrm{C}$ nos dias 2, 4 e 6.

\begin{tabular}{ccccccc}
\hline & \multicolumn{2}{c}{ Dia 2} & \multicolumn{3}{c}{ Dia 4} & \multicolumn{2}{c}{ Dia6 } \\
Tratamento & $10^{\circ} \mathrm{C}$ & $20^{\circ} \mathrm{C}$ & $10^{\circ} \mathrm{C}$ & $20^{\circ} \mathrm{C}$ & $10^{\circ} \mathrm{C}$ & $20^{\circ} \mathrm{C}$ \\
\hline Controle & 12800 & $\mathrm{i}$ & 15767 & $\mathrm{i}$ & $\mathrm{i}$ & $\mathrm{i}$ \\
AM4 & $\mathrm{i}$ & 9733 & 31367 & $\mathrm{i}$ & 4833 & $\mathrm{i}$ \\
AM8 & 19200 & $\mathrm{i}$ & 15967 & $\mathrm{i}$ & 2733 & $\mathrm{i}$ \\
\hline Média & $\mathrm{i}$ & $\mathrm{i}$ & 21033 & $\mathrm{i}$ & $\mathrm{i}$ & $\mathrm{i}$ \\
\hline
\end{tabular}

*Letra i indica valor muito grande de microrganismos, considerados incontáveis.

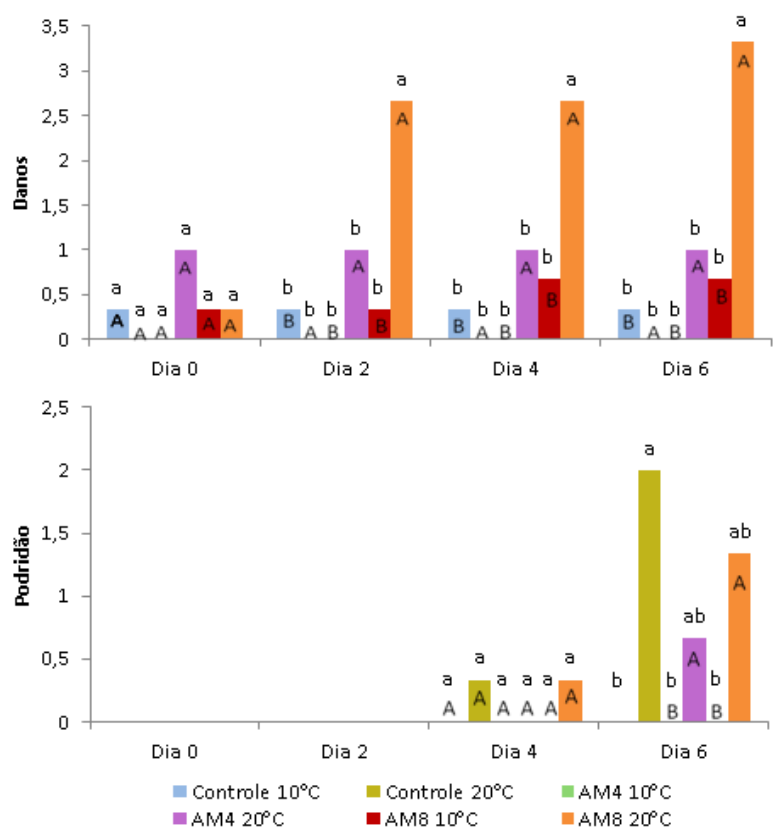

Figura 1. Valores médios de danos e podridão para os tratamentos armazenados à $10^{\circ} \mathrm{C} \mathrm{e} 20^{\circ} \mathrm{C}$ nos dias $0,2,4$ e 6 . Letras minúsculas indicam comparação de médias entre os tratamentos na coluna para um mesmo dia (Tukey, $p<0,05$ ); letras maiúsculas indicam comparação de médias para um mesmo dia entre as temperaturas (Tukey, $p<0,05$ ).

\section{Conclusões}

Os tratamentos à $10^{\circ} \mathrm{C}$ apresentaram melhores resultados, evidenciados pela contenção de microrganismos, danos e podridão, preservando a qualidade e aparência dos frutos.

\section{Agradecimentos}

Ao Cnpq e ao PIBC pela oportunidade e bolsa concedida.

CUNHA, L. C. Jr. Atmosfera controlada na conservação de morangos. p.120 Tese (doutorado). Escola Superior de Agricultura Luiz de Queiroz, Universidade de São Pulo, 2011, 120.

${ }^{2}$ THOMPSON, A. K. Controlled Atmosphere Storage of Fruits and Vegetables. 2.ed. UK: CABI, 2010. 288 